\title{
MANAGEMENT AND CHANGE IN TURBULENT TIMES: HOW DO RUSSIAN SMALL BUSINESS MANAGERS PERCEIVE THE DEVELOPMENT OF THEIR BUSINESS ENVIRONMENT?
}

\author{
Jari Jumpponen ${ }^{1}$, Markku Ikävalko², Timo Pihkala ${ }^{3}$ \\ Lappeenranta University of Technology, Northern Dimension Research Centre, P.O. Box 20, \\ FIN-53851 Lappeenranta, Finland \\ E-mail:1jari.jumpponen@lut.fi; ${ }^{2}$ markku.ikavalko@lut.fi; ${ }^{3}$ timo.pihkala@lut.fi \\ Received 12 November 2007; accepted 19 March 2008
}

\begin{abstract}
This paper focuses on the management of small businesses in Russia. Despite the growing importance of the Russian small business sector, there are surprisingly few empirical studies focusing on this topic. As the business environment in Russia is repeatedly noted to be in constant change, the purpose of the paper is to explore Russian owner-managers perceptions of the development of their business environment from 2000 to 2004 . The paper reports the results of a survey conducted among 164 business managers in North-West Russia.

The results indicate that Russian owner-managers tend to monitor changes in the business environment and adapt their management accordingly, if not beforehand. However, the results are not unambiguous, as the study found wide variations in the extent to which gap the managers monitored and adapted to perceived changes in the business environment.
\end{abstract}

Keywords: Russia, entrepreneurship, strategic management, small business.

\section{Introduction}

In Russia small businesses have a relatively short operational history. Currently, small business contributes some $20 \%$ of Russian GDP, compared with typically $50 \%$ or more in developed market economies. McCarthy et al. (1997) noted that new entrepreneurs in Russia come from the State enterprises and ministries or from academic elite, or they have no work experience in the centralized economy. Further, change in the management in this sector is evident; as Kets de Vries et al. (2004) note, Russian business practices have matured during the past 15 years. For example, Shama and Merrell (1997) describe Russian managers' as changing from directors to managers and Czinkota (1997) highlights that education needs among Russian managers are now similar to those of managers working in Western organizations.

In the mid-1980s there were fewer than 100,000 small companies in Russia. Thus, small business and business managers have a relatively short operational history, and the role of small business is still rather mod- est. The number of small firms in Russia grew quickly from 267,000 in 1991 to 865,000 in 1993. However, after this stage, the number of small business units has stagnated and even declined. Kontorovich (1999) has listed likely causes for this stagnation to include 1) increased tax and regulatory burdens; 2) barriers to entry raised by the authorities; 3 ) the use of new businesses to plunder state-owned firms; and 4) the consequences of the banking crises in 1998 .

Managing Russian enterprises is taking place in an environment, which could be described as turbulent. Traditionally, the response to a turbulent business environment has been to display strong strategic work and strategy management and to choose one's own directions and actions. Another alternative is to simply drift along and hope for the best. In between these two extremes there is a variety of factors, including Russian culture with its own characteristics related to reactive and proactive behaviour. Thus, in small enterprises with scarce resources it is appropriate to explore the extent to which managers rely on these resources and believe them to affect their competitiveness. 
The purpose of this paper is to study the development of Russian management in 2000-2004. Special attention is paid to companies' strengths and weaknesses as well as to the threats and opportunities the companies face - and moreover, how they deal with them. The paper is structured as follows: first we summarize briefly literature on Russian management. We comment on changing patterns of business strategies and quote some researches on Russian business environment development. In the third section we present our data. The fourth section reports the results and the final section summarizes the main conclusions of the study.

\section{Theoretical background}

\subsection{Literature on Russian management in transition}

Omeltchenka \& Armitage (2006) emphasize the importance of leadership practices, as in transitional Russian economy cultural values are under change. Old leadership practices are becoming obsolete and new business leaders are applying new approaches, which are more appropriate for the market-orientated environment.

McCarthy et al. (1997) pay attention to the fact that new entrepreneurs in Russia come from diverse backgrounds. They state that some current entrepreneurs (in the mid-1990s) have been employed in State enterprises and ministries, while others have been members of the technical and cultural elite in academic and research environments. Moreover, some have been students with virtually no work experience in the centralized economy. Shama and Merrell (1997) describe the transformation of Russian management in the early 1990s by defining Russian managers' tendency to develop new managerial styles, changing from directors to managers. They found Russian managers to be active, flexible and open-minded, and often possessing a sales background with strategic and entrepreneurial risk-taking.

The culture typology created by Hofstede (1984, 1991, 1993 ) originally included a four-dimension scale (later he added the fifth dimension). Actually, Russia was not included in the original study, but Hofstede hypothesised about the country. The first dimension of the typology is called power distance and is defined as the degree of equality between people that the population of a country considers to be normal. Hofstede (1993) argued that Russia would be characterized by high power distance; in other words Russians would display high tolerance toward inequality in the society and business relationships. The second dimension, in- dividualism, is the degree to which people in a country prefer to act as individuals rather than members of groups; the opposite of this is collectivism. Russia scores in the medium-range on this dimension. The third dimension, masculinity/femininity, is defined as the degree to which 'masculine' values such as assertiveness, competition, and success are emphasized as opposed to such values as quality of life, warm personal relationships, and service. Russia scores low masculinity on this dimension. The fourth dimension, uncertainty avoidance is the degree to which people in a country prefer structured to unstructured situations. Russia scores high on this dimension of uncertainty avoidance. Hofstede later added a fifth dimension, i. e. short-term - long-term orientation, though this was not thoroughly tested in the original study. Hofstede (1993) argued that Russia would score low in long-term orientation.

Bollinger (1994) also tested Hofstede's hypotheses in his study of Russian managers and found results which concurred with Hofstede's assumptions: high power distance, low tolerance for uncertainty, high appreciation for collectivism, and general equality between men and women workers. More recently, Lapin (2004) found that although these values are still in place, other values are developing, including individualism, risk taking and assertiveness.

In another study (Ardichivili et al. 1998) explored certain characteristics associated with Russian entrepreneurs. Decision-making is done individually ( $25 \%$ of respondents of 258 total) or discussing with other executives ( $32 \%$ of respondents). $30 \%$ of respondents described their leadership style as democratic, whereas $11 \%$ identified themselves as autocratic leaders. Nearly $57 \%$ of respondents described themselves as situational leaders, defining this style as using both autocratic and democratic methods, depending on situation. According to Ardichivili (2001) entrepreneurs were also more likely than managers to use inspirational and charismatic leadership behaviours and to motivate by establishing a direct link between performance and rewards. Managers had higher levels of passive, laissezfaire leadership behaviours than entrepreneurs.

\subsection{Changing patterns of small business strategies}

Resource scarcity is an important concept in the resource-based view of the firm. The resource-based approach (Wernerfelt 1984; Barney 1991) stresses above all the importance of making the most effective use of those resources available. The role of capabilities is vital in determining the way in which the company 
is able to use its resources. Resource scarcity is relevant in this context in two ways: first, small businesses face a constant lack of excess resources and thus they should make strict choices between alternative investment plans. Second, small business managers often lack formal business education and the multitude of managerial tools to guide the development of their company. Thus, resource scarcity can also be seen as the low level of managerial knowledge. However, the lack of a wide array of choices does not necessarily mean low performance; on the contrary. In their study on the competitive repertoires, Miller and Chen (1996) found evidence of the efficacy of the simple competitive repertoires.

Small businesses are generally associated with strategies that are simple, incremental, emergent, informal and unsophisticated. Strategies can be studied as plans, intentions, awareness, orientations or different patterns of company behaviour (e.g. Mintzberg 1978; Gibb and Scott 1985). In a large proportion of studies of strategic choices, the relationship between selected strategy and measured performance has been the basis to single out small business success factors.

There is a vast body of research highlighting the importance of environment monitoring. This is evident especially in the concept of competitive strategies. Cost leadership and differentiation strategies have been studied extensively (Porter 1980; Sandberg and Hofer 1987). In his study on the consensus of strategy decision making, Dess (1987) followed closely Porter's ideas and he suggested an array of competitive methods.

The resources needed in a new venture are manifold, including finance, employees, technology, machinery, facilities, contracts, know-how and experience, to name a few (Penrose 1959; Chatterjee \& Wernerfelt 1991; Lieberman \& Montgomery 1998; Foss 1993; Wiklund 1998). Klofsten uses the concept of 'business platform' to describe the situation where the new venture has been able to secure its flow of resources and is able to utilise those resources in the business process (Klofsten 1998). Thus, the start-up phase would end when the resource flows have been secured. Whilst it is likely that, similar to new ventures, most small businesses are hampered by the resource scarcity, it is reasonable to add the basic resource allocation into the strategy measures.

The most recent addition to strategy measures is networking and inter-firm cooperation (Jarillo 1988; Johannisson 1986). In its most narrow sense, cooperation could be seen as agreements with other firms (e.g.
Aragón-Sanchez and Sánchez-Marín 2005). However, networking is related to the development trend consisting of flexible specialization, focusing on core competencies, grasping of new opportunities through wider market screening and the tightening relationships with suppliers and customers (Pihkala et al. 1999; Vesalainen 2003; Ginevičius, Korsakienė 2004). Thus networking strategy may be seen in various forms, including dyadic partnership building with either suppliers or customers in business to business-environment, or horizontal cooperation between companies seeking to gain scale economies by integrating particular activities together. In the small business context, the main actors in the network strategies formation are the small business managers, and it is common that the business relationships include also social aspects and vice versa.

\subsection{Russian business environment}

Astrakhan and Chepurenko (2003) summarize earlier surveys and analytical studies on the Russian business environment by identifying the main constraints for Russian entrepreneurship development. The most cited obstacles include legal requirements (and bureaucracy), taxation system, access to finance, and lack of business skills and market knowledge.

Hunter (2003) characterises the Russian economy in the beginning of the 21 st century in terms of growing demand but paucity of competition. In addition, he recognizes the lack of skilled economic actors, poorly defined property rights, underdeveloped market institutions, and enduring management practices.

A Moscow-based research center CEFIR (the Center for Economic and Financial Research) in collaboration with the World Bank and USAID has monitored on an annual basis the administrative barriers to small business development in Russia. Their results concerning overall perceptions among entrepreneurs reveal that, after a rather notable improvement of the situation, the sector experienced only slow improvement in 2003, and was then followed by some worsening in 2004 . Most notable is the case of macroeconomic instability, which was the most severe threat to firms in 2001 (value 3.28 on a scale $1-5$ where 1 indicates not a problem and 5 - threat to the existence of the firm). After constant improvement until 2003, this problem was again among the most severe in 2004, even though there were no major cataclysms taking place. During same period competition has become the second most severe problem by 2004 , having been just a minor problem three years before. Concerns about the level of fair competition could be interpreted as implying 
that certain degree of normalization in the case of business environment is taking place. Either there is growing entry to the markets by competing firms or their performance has been developing - or both of these. Further, corruption has gained rather low values in comparison during the monitored period, but this worsened in 2004 (Shetinin et al. 2005).

In view of the above findings from literature, we undertook a survey of managers in St. Petersburg. The main aim of the survey was to a) identify the main threats and opportunities facing their organisations; b) identify the main strengths and weaknesses of their organisations and c) assess managers' perceptions of the development of their organizations during the period 2000-2004. The methodology associated with the survey is presented below.

\section{Data collection and respondents}

Michailova and Liuhto (1999) note that managers and employees in post-socialist organizations are not used to working with people from academia. This lack of experience, in turn, tends to lead to a suspicious and resistant attitude to research. Since in Russia there are these apparent problems, personal interviews (as opposed to a mail survey) were utilized. A total of 164 Russian business owners and managers participated in this study, and data collection took place in early 2005.

Most of the Russian companies were operating in manufacturing - out of the 164 Russian interviewees there were 106 operating in the manufacturing sector, 33 in construction, and 13 in transport, storage and communication sector. The average age of the respondents was 40.4 years. The Company size was represented by two variables: number of personnel and turnover. On average, these Russian companies had 30 employees, which in international comparison could be stated to be a rather high number, as the survey was directed towards small enterprises. However, this partly results from the fact that labour costs, productivity, and value added figures are remarkably low in Russia. Moreover, work is relatively labour-intensive. However, Russian companies also report rather low turnovers - besides, one third did not report these figures at all. Half of the companies had a turnover less than USD 0,2 million, while $10 \%$ of the respondents reported turnover as over USD 1 million. We presume this is due primarily to the Russian respondents' reluctance to reveal the exact figures. Further, the price level of goods (in nominal terms) has been and still remains rather low in Russia. Thus, companies tend to accumulate lower turnover figures.

\section{Results}

In our survey, we asked the St. Petersburg-based managers to name the main threats and opportunities and also main strengths and weaknesses of their company and also to describe the development of the business environment in 2000-2004. From the outset, turbulence of the business environment is visible, when examining the variance in perceptions of business leaders.

\subsection{Main strengths and weaknesses}

First, every company respondent was asked to identify only one main weakness of their business (Table 1).

Table 1. Main weaknesses of the interviewed companies $(n=164)$

\begin{tabular}{lccc}
\hline \multicolumn{1}{c}{ Weakness } & $\mathbf{2 0 0 4}$ & $\mathbf{2 0 0 2}$ & $\mathbf{2 0 0 0}$ \\
\hline Financial problems & 40 & 29 & 27 \\
\hline Human resource problems & 17 & 14 & 13 \\
\hline Problems with equipment & 15 & 13 & 12 \\
\hline Problems with real estate & 7 & 3 & 4 \\
\hline Marketing problems & 6 & 3 & 3 \\
\hline Lack of experience & 2 & 0 & 0 \\
\hline Total number of notions & $\mathbf{8 7}$ & $\mathbf{6 2}$ & $\mathbf{5 9}$ \\
\hline
\end{tabular}

Almost $47 \%$ of the interviewees did not identify any internal weakness, either because they denied having any (perhaps due to the fact that they did not want to reveal them). The managers' awareness of weaknesses could be stated to be increasing, as in comparison with the year 2000 there were some $20 \%$ more managers who identified weaknesses. Some weaknesses have become more severe, and almost all of them have become more problematic as time has elapsed. The most often mentioned main weakness was lack of finance or other financial problems, as every fourth respondent identified it as the main weakness. In this respect the situation has remained unchanged during 2000-2004.

Human resource problems was the second most often mentioned weakness - in 2004 some $10 \%$ of respondents admitted to suffer from it, whereas in 2000 this figure was $8 \%$. In addition, some companies reported problems with marketing or simply "lack of experience". This might not be surprising, but it is interesting to note that these problems were more frequent in 2004 than in 2000 and 2002.

The third most oft-stated weakness related to problems with equipment with $9 \%$ of interviewees citing this as 
the main weakness in 2004. This could be connected with hardships in maintaining, upgrading and modifying equipment in order to develop production. Also problems related to real estate were appearing in 2004 more frequently than in comparison to earlier years. This may be related to rising real estate rents and costs and also an insufficient supply of real estate.

Table 2. Main strengths of the interviewed companies $(n=164)$

\begin{tabular}{lccc}
\hline \multicolumn{1}{c}{ Strength } & $\mathbf{2 0 0 4}$ & $\mathbf{2 0 0 2}$ & $\mathbf{2 0 0 0}$ \\
\hline $\begin{array}{l}\text { Professionalism } \\
\text { of employees }\end{array}$ & 40 & 30 & 29 \\
\hline Strong management & 17 & 6 & 7 \\
\hline Uniqueness of product & 8 & 3 & 4 \\
\hline Developed production & 9 & 10 & 8 \\
\hline Professional experience & 36 & 17 & 16 \\
\hline Flexibility & 5 & 1 & 1 \\
\hline High quality of products & 2 & 1 & 1 \\
\hline Total number of notions & $\mathbf{1 1 7}$ & $\mathbf{6 8}$ & $\mathbf{6 6}$ \\
\hline
\end{tabular}

Taking into account the fact that some $15 \%$ of the companies identified human resource-related issues (including marketing and experience) as the most significant weakness in 2004, it is rather surprising that professionalism of employees and professional experience dominated the strengths $-46 \%$ of companies indicated these to be their key strengths. Specifically, professional experience has been rising according to interviewees - in 2000 it was named as a key strength in $10 \%$ of enterprises, while in 2004 this figure was $22 \%$. Production-related issues (uniqueness, development and high quality) were identified as the main internal strength in $12 \%$ of companies in 2004 . In this respect, the situation has remained almost unchanged in comparison with 2000 and 2002. Thirdly, strong management was cited as a key strength in $10 \%$ of responses in 2004, which is twice the figure reported in 2000 .

Even though human resources and management of human resources are widely recognized as problematic, small enterprises do not seem to have any other alternative, but to believe it to be the most important strength of the company. This belief is held by $25 \%$ of our respondents. Moreover, when there is only a narrow variety of products, more emphasis is laid on human resources. Human resources are developed in a situation, where infrastructure and equipment are still underdeveloped. Investment in infrastructure and equipment are seen too risky in the turbulent development phase of the business environment.

Some $60 \%$ of the respondents could not identify or remember any strength to have been experienced in 2000, while in 2004 this figure was only $30 \%$.

\subsection{Threats and opportunities}

Threats and business constraints have been discussed widely in research related to emerging economies and economic transition. Our survey respondents were asked to identify their most critical external threats. This question provided a range of interesting responses. The turbulence and sheer pace of the development of the business environment is clearly evident from the responses provided. First, the instability of the Russian economy remained the most significant threat during the period 2000-2004, and with a notably high share; every fourth respondent agreed it to be the main threat in 2004, even though the Russian economy has experienced fast growth. Second, competition has become a more severe problem; in 2000, $7 \%$ of respondents perceived it to be the most severe 'threat', while in 2004 this figure had increased to $12 \%$ of the respondents. The rise of competition in this context is interesting, because it could be assumed to mean that, to some extent, the economy is developing in a "normal" direction. Third, legislation had also become a more severe threat and in 2004 some $10 \%$ of respondents reported it to be the most significant threat to their organizations.

Table 3. Most critical threats $(n=164)$

\begin{tabular}{lccc}
\hline \multicolumn{1}{c}{ Threat } & $\mathbf{2 0 0 4}$ & $\mathbf{2 0 0 2}$ & $\mathbf{2 0 0 0}$ \\
\hline $\begin{array}{l}\text { Instability of Russian } \\
\text { economy }\end{array}$ & 40 & 37 & 37 \\
\hline Competition & 20 & 14 & 12 \\
\hline Russian legislation & 16 & 12 & 11 \\
\hline Decrease in market demand & 8 & 6 & 5 \\
\hline $\begin{array}{l}\text { Increase in costs for facilities } \\
\text { and raw materials }\end{array}$ & 9 & 6 & 5 \\
\hline Delays in payments & 5 & 3 & 3 \\
\hline Corruption, bureaucracy & 3 & 2 & 2 \\
\hline Total number of notions & $\mathbf{1 0 1}$ & $\mathbf{8 0}$ & $\mathbf{7 5}$ \\
\hline
\end{tabular}

Even though the Russian economy has been growing rapidly in recent years, some respondents noted a "decrease in market demand" as the main threat they faced. Similarly, increases in raw material prices and 
facilities were noted. Corruption and bureaucracy were not reported as a significant threat by the vast majority of respondents; in fact, only three of the respondents named it as the main threat. Respondents were asked to state how many working hours on a weekly basis managers spend on overcoming bureaucracy. On average respondents used $20 \%$ of their working hours in 2004 tackling bureaucracy, while in 2000 this figure was $19 \%$. Thus, it could be stated that despite aims to remove administrative constraints, there are no signs of diminishing bureaucracy.

Table 4. Main opportunities $(n=164)$

\begin{tabular}{lccc}
\hline \multicolumn{1}{c}{ Opportunity } & $\mathbf{2 0 0 4}$ & $\mathbf{2 0 0 2}$ & $\mathbf{2 0 0 0}$ \\
\hline Market expansion & 68 & 49 & 49 \\
\hline Enlarging the company & 26 & 16 & 16 \\
\hline Partnership & 11 & 9 & 44 \\
\hline Technology development & 4 & 5 & 5 \\
\hline Total number of notions & $\mathbf{1 0 9}$ & $\mathbf{7 9}$ & $\mathbf{1 1 4}$ \\
\hline
\end{tabular}

Opportunities were mostly connected to growing markets; over $40 \%$ of respondents reported this to be the best opportunity. Also enlarging the company is widely accepted as an opportunity. The respondents indicated that growth is most probably achievable in the current circumstances by relying on good personnel. Interestingly, partnership had been seen as opportunity in 2000 with $27 \%$ share, while in 2004 only $7 \%$ mentioned partnership as most significant opportunity.

Respondents were also asked about their attitude towards the possible appearance of new companies operating in their field. The majority of respondents (53\%) reported that they would probably try to collaborate however, only a minority was able to say how they would collaborate. One third reported that new potential competitors would not change their situation due to the fact that market demand is high and every company can have its niche. (One respondent claimed to have such loyal customers that a new provider would not affect his business.) Some $7 \%$ of the companies saw new market entrants generally as positive, because they increase competitiveness.

In her study on enterprise restructuring, Linz (2001) reported that none out of 32 studied former state-owned firms spent money on research and development in 1998. In our study, the outcome was more complicated. Even though our respondents stated that they spent, on average, some $28 \%$ of their profits on research and development activities, only a few respondents consid- ered technology development as the main opportunity for their company. In addition, product-related aspects (uniqueness, development and high quality) were reported as a strength by $12 \%$ of respondents. Therefore, even though companies reported spending notable efforts on research and development, the benefits of these efforts were not noted.

\section{Conclusions}

The purpose of this paper was to study the development of managers' perceptions of the strengths, weaknesses, threats and opportunities in relation to small Russian companies. On the basis of our findings, companies tend to have a resource-based view, even though resources are scarce and on the low development level. Improved stability of regulatory and economic-political environment is seen as the most likely way of ensuring the development of these resources.

It has been noted elsewhere that there are certain survival strategies, which small business enterprises may utilize. First, there is the opportunistic strategy, which means following business opportunities. Based on earlier studies, in Russian context this has meant changing the business field frequently according to world market prices (Astrakhan \& Chepurenko 2003). Second, the risk-avoiding strategy means refraining from growth and sustaining the existing way of doing business. Third, the resource utilization strategy refers to utilizing one's own current strengths (for example, professional personnel) as completely as possible. Finally, the resource collecting strategy emphasizes addressing weaknesses, which means strengthening the resource base by networking or through various purchase strategies.

Veiga et al. (1995) stated that young Russian managers tend to be less authoritative in comparison with older managers. In addition, young managers have started planning for longer periods of time whereas their older counterparts have remained short-term focused. This is explained by stating that younger managers have to rely more on themselves to ensure the long-term success of their company, whereas older managers are experienced in operating centrally-planned economy with strong governmental regulation.

Yet despite this knowledge which is already in the public domain, the business planning horizon of approximately half of this sample of managers, all based in St Petersburg, was still short; $6 \%$ of respondents acknowledged it to be less than one year and $31 \%$ reported a horizon of approximately 1 year. However, 
almost $50 \%$ of the respondents reported their planning horizon to be 3 years or more, which could be interpreted as meaning that, at least in the case of some companies, future planning has been adapted to management practices. Unlike Veiga et al. (1995), we did not find a positive correlation between long-term planning and young managers. On the contrary, according to our results, there is weak but significant (sig. 0.05) negative correlation, i.e. older respondents in our survey tended to have longer business planning horizon than younger managers.

Finally, there is apparent need for further research concerning not only business managers' perceptions of the development of the turbulent Russian market, but also on their survival strategies.

\section{References}

Aragón-Sanchez, A.; Sánchez-Marin, G. 2005. Strategic orientation, management characteristics, and performance: a study of Spanish SMEs, Journal of Small Business Management 43(3): 287-308.

Ardichivili, A.; Cardozo, R. N.; Gasparishvili, A. 1998. Leadership styles and management practices of Russian entrepreneurs: implications for transferability of Western HRD interventions, Human Resource Development Quarterly 9(2): 145-156.

Astrakhan, I.; Chepurenko, A. 2003. Small business in Russia: any prospects after a decade? Futures 35 : 341-359.

Barney, J. 1991. Firm resources and sustained competitive advantage, Journal of Management 17(1): 99-120.

Bollinger, D. 1994. The four cornerstones and three pillars in the 'House of Russia' management system, The Journal of Management Development 13(2): 49-54.

Chatterjee, S.; Wernerfelt, B. 1991. The link between resources and type of diversification: theory and evidence, Strategic Management Journal 12(1): 33-48.

Czinkota, M. R. 1997. Russia's transition to a market economy: Learning about business, Journal of International Marketing 5(4): 73-93.

Dess, G. G. 1987. Consensus on strategy formulation and organizational performance: competitors in a fragmented industry, Strategic Management Journal 8: 259-277.

Fey, C. F.; Adaeva, M.; Vitkovskaia, A. 2001. Developing a model of leadership styles: what works best in Russia? International Business Review 10(6): 615-643.

Foss, L. 1993. Resources, networks and entrepreneurship: a survey of 153 starters and 84 non-starters in the cod farming industry in Norway, in Frontiers of Entrepreneurship Research, Babson Park, MA: Babson College.

Gibb, A.; Scott, M. 1985. Strategic awareness, personal commitment and the process of planning in the small business, Journal of Management Studies 20(6): 597-631.
Ginevičius, R.; Korsakienè, R. 2004. Influence of marketing on business: theoretical and practical aspects, Business: Theory and Practices 4(3): 109-115.

Hofstede, G. 1984. Culture's consequences - international differences in work-related values. Sage Publications, USA.

Hofstede, G. 1991. Cultures and organizations - software of the mind. McGraw-Hill book company, London.

Hofstede, G. 1993. Cultural constraints in management theories, Academy of Management Executive 7(1): 81-94.

Hunter, J. G. 2003. Determinants of business success under "hypocapitalism", Case studies of Russian firms and their strategies, Journal of Business Research 56(2): 113-120.

Jarillo, J. C. 1989. Entrepreneurship and growth: the strategic use of external resources, Journal of Business Venturing 4: 133-147.

Johannisson, B. 1986. Network strategies: management technology for entrepreneurship and change, International Small Business Journal 5(1): 19-30.

Kets de Vries, M.; Shekshnia, S.; Korotov, K.; FlorentTreacy, E. 2004. The new global Russian business leaders: lessons from a decade of transition, European Management Journal 22(6): 637-649.

Klofsten, M. 1998. The business platform - entrepreneurship \& management in the early stages of a firm's development. Luxembourg: TII asbl Luxembourg.

Kontorovich, V. 1999. Has new business creation in Russia come to a halt? Journal of Business Venturing 14: 451-460.

Lapin, N. I. 2004. How the citizens of Russia feel and what they are striving for, Sociological Research 43(2): 6-23.

Lieberman, M. B.; Montgomery, D. B. 1998. First-mover (dis)advantages: retrospective and link with the resourcebased view, Strategic Management Journal 19(12): 1111-1125.

Linz, S. J. 2001. Restructuring with what success? a case study of Russian firms, Comparative Economic Studies 43(1): 75-99.

McCarthy, D.; Puffer, S.; Naumov, A. 1997. Partnering with Russia's new entrepreneurs: software Tsarina Olga Kirova, European Management Journal 15(6): 648-657.

Michailova, S.; Liuhto, K. 1999. Organisation and management research in transition economies: towards improved research methodologies. CEES Working Paper No. 19, Center for East European Studies, Copenhagen Business School.

Miller, D.; Chen, M.-J. 1996. The simplicity of competitive repertoires: an empirical analysis, Strategic Management Journal 17: 419-439.

Mintzberg, H. 1978. Patterns in strategy formation, Management Science 24(9): 934-948.

Omeltchenka, A. E.; Armitage, A. 2006. Leadership prototypes: a Russian perspective, Baltic Journal of Management 1(3): 315-338. 
Penrose, E. 1959. The theory of the growth of the firm. III ed. New York: Oxford University Press.

Pihkala, T.; Varamäki, E.; Vesalainen, J. 1999. Virtual organization and the SMEs: a review and model development, Entrepreneurship and Regional Development 11(4): 335-349.

Porter, M. E. 1980. Competitive strategy, New York: Free Press.

Puffer, S. M. 1996. Leadership in a Russian context, in Business and Management in Russia, Ed. Sheila M. Puffer. Edward Elgar Publishing Company.

Sandberg, W. R.; Hofer, C. W. 1987. Improving new venture performance, the role of strategy, industry structure and the entrepreneur, Journal of Business Venturing 2: 5-28.

Shama, A.; Merrell, M. N. 1997. Russia's true business performance: inviting to international business? Journal of World Business 32(4): 320-332.

Shetinin, O.; Zamulin, O.; Zhuravskaya, E.; Yakovlev, E.
2005. Monitoring the administrative barriers to small business development in Russia. $5^{\text {th }}$ Round, CEFIR Policy Paper series No. 22, Center for Economic and Financial Research at New Economic School, Moscow.

Veiga, J. F.; Yanouza, J. N.; Buchholtz, A. K. 1995. Emerging cultural values among Russian managers: what will tomorrow bring? Business Horizons 38(4): 20-27.

Vesalainen, J. 2003. Kaupankäynnistä kumppanuuteen. Metallisteollisuuden keskusliitto. MET, Helsinki.

Wernerfelt, B. 1984. A Resource-based view of the firm, Strategic Management Journal 5: 171-180.

Wiklund, J. 1998. Small firm growth and performance. A Dissertation for the Doctor's Degree, Jönköping International Business School.

Zhuplev, A.; Konkov, A.; Kiesner, F. 1998. Russian and American small business: motivations and obstacles, European Management Journal 16(4): 505-516. 